Paula Puškárová ${ }^{1}$

Institute for Economics and Management, University of Economics in Bratislava

Štefan Zajac ${ }^{2}$

Institute for Economics and Management, University of Economics in Bratislava

\title{
Innovation and Competitiveness of the Slovak Economy: New Evidence of International Impacts in the Knowledge Accumulation Process
}

\begin{abstract}
The objectives of this paper are twofold - to demonstrate the internal forces driving $R \& D$ productivity in Slovakia and the internationalization of Slovak R\&D investments and R\&D patenting since EU accession as compared to the other Visegrad Four (V4) countries. After the Introduction, Slovakia's position in the field of competitiveness and the Slovak innovation policy are described. The Slovak knowledge accumulation paradox being the discrepancy between R\&D productivity and TFP is then demonstrated and disentangled through an analysis of innovation activities using Eurostat and OECD Stat data spanning the 1995-2011 period. This analysis is followed by some concluding remarks.
\end{abstract}

Keywords: Slovak economy, competitiveness, innovation performance; education and labor market; Visegrad Four countries, innovation policy

JEL: F43, O31, O47 


\section{Introduction}

The competitiveness of a national economy is a complex phenomenon. Generally, a country's competitiveness is its ability to successfully compete with the economies of other countries, manifested in terms of relative prosperity (e.g. productivity growth and living standards). Here, competitiveness performance is assessed in terms of total factor productivity (TFP), which captures how efficiently labor and capital are employed in production and implicit, are attractive for foreign markets. This productivity-based approach to competitiveness is less concerned with standards of living, although it may be assumed that higher productivity is followed by higher incomes, consumption and general living standards.

After the Slovak accession to the EU, indicators of the competitiveness and innovation performance of the Slovak economy have been of dual character. Some competiveness indicators converge to the EU average while others are similar to those reported by the less developed countries [Šikula et al., 2010]. According to The Global Competitiveness Report 2012-2013 (and prior years), as compared to neighboring countries and the rest of the European Union, Slovakia has not scored well. More generally, in the 2010-2013 period, Slovakia's rank in the Global competitiveness index fell from the 60th to 71st position (out of 144 countries). In the basic requirement and efficiency enhancers, as well as business sophistication, Slovakia ranked somewhat better - being 62nd, 51st, and 61st, respectively.

However, Slovakia was ranked last among all the EU countries, and 89th overall. This poor ranking can be explained by low levels of R\&D spending (particularly in terms of business expenditures) and such other, more general, factors as corruption, weak rule of law insufficient infrastructure, inefficient labor market, and quality of the educational system. It is a mix of qualitative catch-up and quantitative lagging.

Thus, it is challenging to quantitatively report the influence of innovation performance on a competitive economy, and presumed that other factors have shaped competitive performance in the Slovak economy, which exhibits a trajectory of relatively strong economic growth despite low innovation performance [Puškárová, 2012]. These other factors likely relate to EU membership and increasing openness to international capital flows, labor and trade in the face of strong domestic inertia effects.

A reasonable amount of empirical evidence appears in the current literature that international capital flows (such as foreign direct investments), labor and international trade spur economic growth measured in terms of GDP, and also implicate certain externalities. When labor, capital or goods and services are transferred from innovation intensive countries (e.g., West European EU members), a knowledge base accompanies that transfer [Keller, 2010]. For example, when a German company opens a subsidiary in Slovakia, Slovak workers are trained to work effectively with their German co-workers, 
and generally held to German work standards. Similarly, Austrian product imports also convey marketing, taste, packaging, and other information to the domestic market which may help local Slovak entrepreneurs copy, complement, or develop substitutes for, the products being imported. Labor - the first and ultimate producer of knowledge - carries skills and passes knowledge across borders. And, where foreign knowledge leads to greater competitive performance, domestic knowledge loses significance for domestic TFP growth [Krammer, 2014; Keller, 2010; Puškárová, 2012], as dependence on outside knowledge sources increases.

The empirical evidence is that Slovak GDP and competitiveness in terms of productivity has been growing, but innovation performance is lagging. The theoretical grounds of our paper relate to the aggregate Cobb-Douglas production function employed in numerous studies [including, among others, Dujava, 2012; Puškárová, 2012] to study competitiveness (using a productivity-based approach) and foreign impacts through labor and capital, which are the standard two production inputs in the Cobb-Douglas production function. Productivity is then viewed as a residual value between GDP (output) and labor and capital (inputs) with respect to production input shares ${ }^{3}$.

The paper is organized as follows: in the upcoming section, current innovation and R\&D policy in Slovakia are described with sufficient detail to better understand the shift in the Slovak government's approach towards internal and international forces shaping competitiveness and innovation performance. In section 3, the magnitude of the discrepancy between competitiveness and innovation performance in Slovakia is demonstrated, using economic theory as applied to relevant variables. In sections 4 and 5, we analyze various indicators of human and knowledge capital at the domestic and international levels which, in accordance with our theoretical framework, impact the discrepancy phenomenon and reveal the true nature of the internationalization of Slovak R\&D performance. Section 6 provides concluding remarks.

\section{Competitiveness and Innovation Policy of the Slovak Republic}

Innovation policy can be defined as a set of policy actions purposefully designed to raise the quantity and efficiency of innovation activities, where "innovation activities" refer to the creation, adaptation and adoption of new or improved products, processes or services. Such a policy was missing in Slovakia, in the first half of the 2000s, during which the approach to innovation was based on a traditional science and technology policy model (i.e., the science and technology push model).

After the EU accession, several important policy documents on innovation were prepared in the 2007-2011 period by the Ministry of Economy, and approved by the Slovak government. These included: 
1. Innovation strategy of the Slovak Republic for 2007-2013 [Ministry of Economy, 2007];

2. Innovation Policy in the Slovak Republic for 2008-2010 [Ministry of Economy, 2008]; and

3. Innovation Policy in the Slovak Republic for Slovak Republic for 2011-2013 [Ministry of Economy, 2011].

The strategic objective of Slovakia's innovation strategy [Ministry of Economy, 2007], as adopted by the Government of the Slovak Republic on 14 March 2007, was to achieve the level of the most advanced economies of the European Union by using innovation as a primary tool of knowledge based economic development. To do so, the innovation strategy prioritized remedying insufficient support of innovative activities (particularly for SMEs) within the context of several key national-level strategic documents. While Slovak firms were innovating, they were in relative terms unduly handicapped and less competitive. Motivating businesses to use multi-source support to financing from public, international and business sources (particularly the latter two sources) became a priority.

Another critically important task was to create a national innovation system in Slovakia that included regional innovation structures (incubators, innovation centers, consulting center, and other elements). These regional structures are intended to bring support activities as close to entrepreneurs as possible, with an emphasis on small and medium-sized enterprises. By 2013, this innovation system was expected to achieve:

- a positive trend in the development of innovative processes reflected in the economy and social area;

- an increased number of successfully implemented projects;

- a $25 \%$ contribution to increased gross domestic product growth (presently that contribution is about $8 \%$ ),

- transform over 50\% of industrial and service companies, particularly SMEs, into innovators.

The Innovation Policy of the Slovak Republic for 2008 - to 2010 was primarily based on the Innovation Strategy. The basic goal of the innovation policy was to create support mechanisms for the formation and development of regional innovation structures, innovation enterprises, partnership and cooperation of companies, and universities in the R\&D field, so as to gain new markets in a sustainable environment. In particular, this involved the following:

1. improving competitiveness of businesses while adhering to the principles of sustainable development;

2. increasing the expertise and flexibility of labor; and

3. regional development.

To attain these objectives it was considered as necessary to:

- build-out innovation support structures capable of absorbing and efficiently deploying funds allocated in accordance with the Innovation Strategy of the SR; 
- prepare and implement support programs, projects, and schemes; and

- establish a network of regional innovation centers - RICs.

It should be mentioned, that Innovation Policy in the Slovak Republic for 2011 - to 2013 reflects the OECD recommendations listed in the November 2010 Economic Survey of the Slovak Republic, which emphasized long-term structural and eco-innovation effects. The objective of this Policy were to: support the creation and development of innovation structures, businesses, and partnerships; foster cooperation among businesses, universities, and research institutes in R\&D and innovation; and establish conditions for improving Slovakia's competitiveness. The 2011-2013 Innovation Policy was designed s to fit the EU policy framework and serve as a specific program for pursuing the national interests of the Slovak Republic. This objective reflects the greatest challenge currently facing Slovakia (and the rest of the EU), i.e., the inability to fully harness and share research and development results, and reflect them in economic and social values. The gap between research results and their practical application remains wide.

More generally, individual Innovation Policy priorities follow the priorities set out in the Innovation Strategy for 2007-2013. They are as follows:

Priority 1 - High-quality infrastructure and an efficient system for innovation development (to include supporting innovative industrial cluster organizations, promoting innovation and the building of innovation awareness across the society, enhancing competition, introducing an "Innovative Action of the Year", developing Strategic Innovation Material for the Next Planning Period, and supporting projects applying for funding from Community Programs to support innovation);

Priority 2 - High-quality human resources (to include lifelong learning and counselling system, and secondary vocational education); and

Priority 3 - Efficient tools for innovation (to include a national incentive project to enhance Slovakia's innovation, facilitating operational program competitiveness and economic growth, supporting financial engineering instruments, such as innovation funding increased public spending on innovation and innovation vouchers, and strengthening intellectual property protection).

Generally speaking, these policy documents addressed a number of previously neglected areas and tackled several problems with creation of the Slovak national innovation system. However, the links between innovation policy and existing sectoral policies are weak (e.g., R\&D policy, which is managed by the Ministry of Education) and have not yet entered the policy agenda. Slovakia should better co-ordinate innovation policy across government bodies and clearly define competencies in the area of innovation and $\mathrm{R} \& \mathrm{D}$. All objectives mentioned above would require deep changes, which necessarily take to have real effects, can only be expected in the long-term. 


\section{Development of the Slovak R\&D Sector}

As previously mentioned, this paper is concerned with the disparity in Slovakia between competitiveness and innovation performance. In this section, this disparity is demonstrated. To measure competitiveness, the productivity-based approach is employed, measured using the Total Factor Productivity (TFP) calculated from the Cobb-Douglas production function:

$$
Y_{i t}=A_{i t} L_{i t}^{\alpha} C_{i t}^{1-\alpha} E \exp \left(\varepsilon_{i t}\right)
$$

where $Y_{i t}$ denotes output, $L_{i t}$ labor, $C_{i t}$ physical capital, and $A_{i t}$ is TFP. The exponential error term $\varepsilon_{i t}$ is the error term and is assumed to be identically and independently distributed with mean zero and standard deviation $\sigma^{2} . \alpha$ and 1- $\alpha$ are the output elasticities with respect to labor and physical capital. The Eq. (1) is in a two-dimensional form - $i$ denotes geographical unit (region, state, company) and $t$ denotes time unit (year, month etc.).

In order to report innovation performance, two approaches are suggested by the literature. One approach is to measure it as output $K_{i t}$ or productivity $\delta_{i t}$ of the knowledge-generating process where the only factor is human capital $H_{i t}$ [Jones, 1995].

$$
\Delta K_{i t}=\delta_{i t} H_{i t}^{\beta} K_{i t-1} \omega_{i t}
$$

$\beta$ is the elasticity parameter of knowledge capital to human capital changes. $\omega_{i t}$ stands for the error term. $\delta_{i t}$ stands for productivity of R\&D process - in this case mostly for productivity of human capital in case the impact of omitted variables remains stable.

An alternative approach is through the lens of the investments (capital) in R\&D and how productive they are. In its simplest form, we can measure this productivity as the elasticity of the output - knowledge capital - to the inputs - R\&D investments.

$$
E_{i t}=\log _{s_{i t}} K_{i t}
$$

where $E_{i t}$ stands for output elasticity, $S_{i t}$ for R\&D investments and $K_{i t}$ for knowledge capital measured using patents or patent applications volume. Following this approach, we take the $R \& D$ expenditures (referred to as Gross Expenditures on R\&D (GERD) in Eurostat databases) per year and country as the measure of $S_{i t}$ and number of patent applications to the European Patent Office (EPO) as a proxy for knowledge capital in a country $i$ and time $t$. Both show a strong divergence amongst the V4 countries (Figures 1 and 2). 


\section{FIGURE 1. R\&D expenditures, \% GDP}

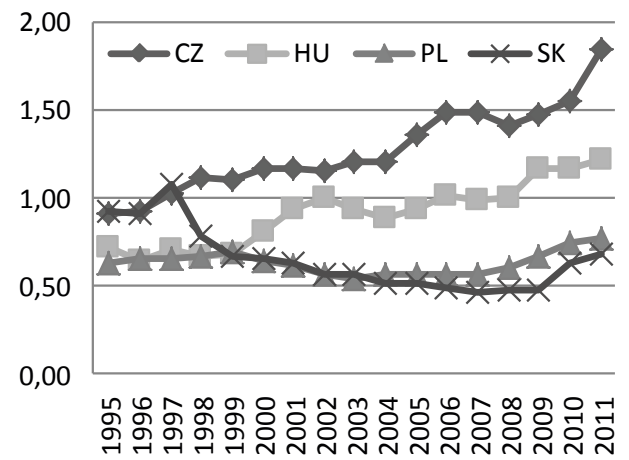

FIGURE 2. EPO patent applications

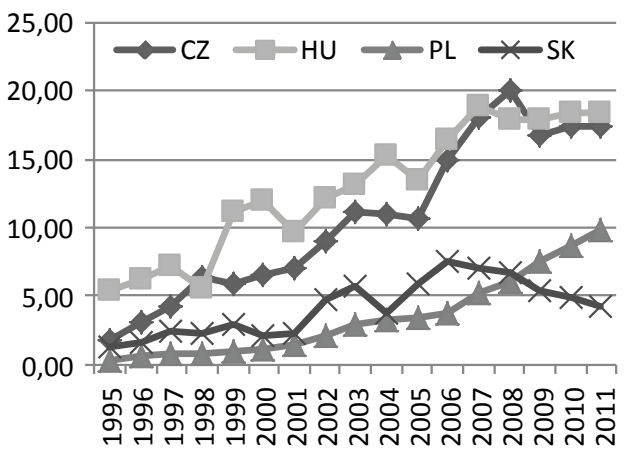

S o u r c e: Eurostat 2014 - Total intramural R\&D expenditures (GERD); Patent applications to the EPO by priority year at the national level per million inhabitants.

In terms of $\mathrm{R} \& \mathrm{D}$ expenditures (Figure 1), the V4 countries expended roughly equivalent volumes of their GDP in the pre-transition and transition eras. In 1998, changes in Slovak government (the right wing came to power) negatively affected R\&D funding. A restrictive $R \& D$ policy at that time redirected budget attention away from the $R \& D$ sector, leading to a substantial divergence in Slovakia's R\&D output (Figure 2). However, a comparison of Figures 1-2 indicates that the theorem that the more R\&D input, the more R\&D output, does not appear to strictly hold. The challenging case is Hungary, which produces as many European Patent Office (EPO) patent applications as the Czech Republic, where more is expended in R\&D. This issue is addressed below.

Figures 1-2 might also imply that in $\mathrm{R} \& \mathrm{D}$, persistence pays off. For example, low R\&D spending Poland over time has not prevented the accrual of patent applications filed with the EPO, which is not the case of Slovakia, where patenting follows a more unstable trajectory. As compared to the EU average (65.31 in 1995 and 107.45 in 2011, i.e. a growth rate of $64.5 \%), \mathrm{V} 4$ countries file far fewer patent applications with the EPO. However, after the V4's EU accession, the biggest trading partners of the V4 - Germany, France and Netherlands - experienced patent stagnation (which decreased in the Netherlands). Only Austria managed to file $9 \%$ more EPO applications during this period.

Calculating the elasticity $E_{i t}$ gives us the following results (Figure 1) which we can compare with the trajectory of the Total Factor Productivity (TFP). Hereinafter, this productivity is referred to as R\&D productivity. 
FIGURE 3. Elasticity of $K_{i t}$ on $S_{i t}$

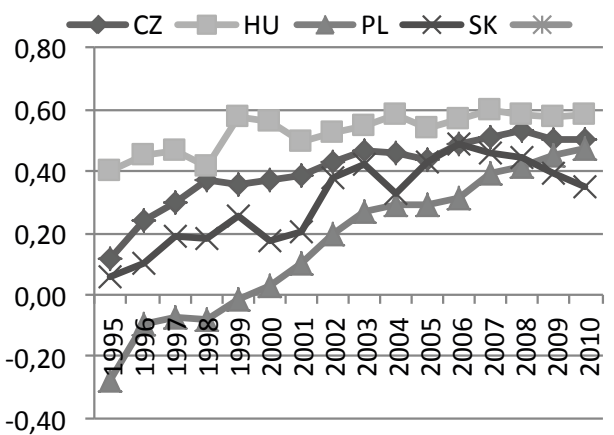

FIGURE 4. Impact of the TFP on GDP

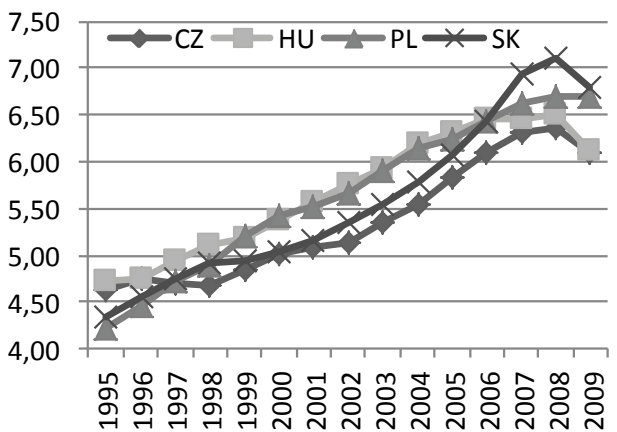

S o u r c e: author's own calculations, TFP calculated following Dujava (2012), GDP (gross domestic product) taken from Eurostat 2014 in EUR.

As expected, Figure 3 shows these R\&D productivities at less than 1 (diminishing returns to scale), as Jones' model [1995] predicts for human capital. This may be imputed to the nature of the knowledge generation process ( $\& \mathrm{D}$ are risky investments without any guarantee of useful outcome), the effects of an unobservable pool of knowledge (not covered by patentable knowledge), and/or to duplicity of work (multiple projects working on the same issue). Figure 3 reports that though the V4 countries still lag significantly behind the EU15 (R\&D productivity accounting there for approx. 0.8), convergence in the V4 of R\&D productivity is present.

The one exception is Slovakia, where R\&D productivity continues to drop since EU accession. The data presented in the Figures 1 through 3 are unambiguous. Slovakia is doing poorly in terms of $\mathrm{R} \& \mathrm{D}$, but has been experiencing the highest growth of TFP (Figure 4). This accords with the empirical observation mentioned previously; namely, a disparity between competitiveness and innovation performance. We call this empirical phenomenon the Slovak knowledge accumulation paradox and, as indicated earlier in the text, the upcoming sections will try to analyze this paradox. In particular, we explore why domestic R\&D performance is so low (e.g., what internal forces shape their trajectory) and why the competitiveness measured in terms of TFP is so high (e.g., how large part the international parties play here).

\section{Internal Forces Driving R\&D Productivity}

First, we look at sectors where R\&D is performed (public, private, and university), since we assume that they differ by productivity. Table 1 shows that Poland and Slovakia research more or less equally in all three sectors. By contrast, Hungary and the Czech Republic rely heavily on research in the business sector, which is claimed to be the most productive and indeed, does translates into higher R\&D productivity (Figure 3). 
Combining Table 1 with R\&D expenditures by sector (Table 2), the business sector in all V4 countries performs R\&D only to the extent of its own investment, which indicates $\mathrm{R} \& \mathrm{D}$ is not outsourced to public institutions. The government, on the other hand, is a key investor in university research.

\section{TABLE 1. R\&D performance in sectors}

\begin{tabular}{|l|c|c|c|c|c|c|c|c|c|c|c|c|}
\hline & $\begin{array}{c}\text { CZ } \\
\text { bus }\end{array}$ & $\begin{array}{c}\text { CZ } \\
\text { gov }\end{array}$ & $\begin{array}{c}\text { CZ } \\
\text { uni }\end{array}$ & $\begin{array}{c}\text { HU } \\
\text { bus }\end{array}$ & $\begin{array}{c}\text { HU } \\
\text { gov }\end{array}$ & $\begin{array}{c}\text { HU } \\
\text { uni }\end{array}$ & $\begin{array}{c}\text { PL } \\
\text { bus }\end{array}$ & $\begin{array}{c}\text { PL } \\
\text { gov }\end{array}$ & $\begin{array}{c}\text { PL } \\
\text { uni }\end{array}$ & $\begin{array}{c}\text { SK } \\
\text { bus }\end{array}$ & $\begin{array}{c}\text { SK } \\
\text { gov }\end{array}$ & $\begin{array}{c}\text { SK } \\
\text { uni }\end{array}$ \\
\hline 1995 & 65.1 & 8.5 & 26.4 & 43.4 & 24.8 & 25.6 & 38.7 & 26.3 & 35.0 & 53.9 & 5.9 & 40.2 \\
\hline 2000 & 60.0 & 14.2 & 25.3 & 44.3 & 24.0 & 26.1 & 36.1 & 31.5 & 32.2 & 65.8 & 9.5 & 24.7 \\
\hline 2005 & 63.2 & 16.4 & 20.0 & 43.2 & 25.1 & 28.0 & 31.8 & 31.6 & 36.4 & 49.8 & 20.4 & 29.7 \\
\hline 2010 & 62.0 & 18.0 & 19.4 & 59.8 & 19.9 & 18.5 & 26.6 & 37.2 & 35.9 & 42.1 & 27.6 & 30.0 \\
\hline 2011 & 60.3 & 21.6 & 17.5 & 62.4 & 20.2 & 15.8 & 30.1 & 35.1 & 34.5 & 37.2 & 34.9 & 27.7 \\
\hline
\end{tabular}

Notes: bus refers to business $\mathrm{R} \& \mathrm{D}$, gov to government $\mathrm{R} \& \mathrm{D}$, and uni to university $\mathrm{R} \& \mathrm{D}$ performance; private non-profit R\&D expenditures are excluded as their shares are negligible low (on average, the lowest value among V4 - 0.19\% in Slovakia, the highest value among V4 - 0.49\% in Hungary).

S o u r c e: Eurostat 2014 - Total intramural R\&D expenditure (GERD) by sectors of performance.

One can observe that the innovation-intensive countries demonstrate a high share of business R\&D. This is at least partially because business R\&D expenditures are more profitable and produce returns sooner than public ones, as they are driven by the profit motive and therefore constantly pursue competitive market advantages. Table 2 shows that this theorem also holds for the V4, in which countries filing more EPO patent applications demonstrate higher business R\&D expenditures (even though Hungary activated its business $R \& D$ in 2002). These levels converge at the ends of the spectrum (i.e., the best and worst performing $\mathrm{V} 4$ countries), but divergence for those occupying the middle ground. The closing levels in Hungary and the Czech Republic are approximately double the levels in Slovakia and Poland. Correspondingly, public R\&D expenditures shrunk in the Czech Republic and Hungary and were augmented in Slovakia and Poland.

From Table 2, it appears that in the Czech Republic knowledge is mostly accumulated through domestic business $R \& D$ stimulated by a multiplier of public $R \& D$ on private $R \& D$ [Šikula, 2010] - conventional multiplier. In fact, the Czech Republic is uniquely positioned compared to its $\mathrm{V} 4$ counterparts - it demonstrates approximately the same public/private ratio of domestic $\mathrm{R} \& \mathrm{D}$ spending as the $\mathrm{R} \& \mathrm{D}$-intensive countries usually do (75\%). The question remains why, despite this long-term, consistently maintained structure, the country exhibits a relatively low volume of $R \& D$ output (Figure 2 ). It may be that in the Czech Republic there still exists a large technology gap with R\&D-intensive Western EU countries, and human capital might be more closed to knowledge transfer from abroad than it is in other V4 countries [consistent with the results of Krammer, 2014]. 
TABLE 2. R\&D funding by sectors

\begin{tabular}{|l|c|c|c|c|c|c|c|c|c|c|c|c|}
\hline & $\begin{array}{c}\text { CZ } \\
\text { bus }\end{array}$ & $\begin{array}{c}\text { CZ } \\
\text { gov }\end{array}$ & $\begin{array}{c}\text { CZ } \\
\text { uni }\end{array}$ & $\begin{array}{c}\text { HU } \\
\text { bus }\end{array}$ & $\begin{array}{c}\text { HU } \\
\text { gov }\end{array}$ & $\begin{array}{c}\text { HU } \\
\text { uni }\end{array}$ & $\begin{array}{c}\text { PL } \\
\text { bus }\end{array}$ & $\begin{array}{c}\text { PL } \\
\text { gov }\end{array}$ & $\begin{array}{c}\text { PL } \\
\text { uni }\end{array}$ & $\begin{array}{c}\text { SK } \\
\text { bus }\end{array}$ & $\begin{array}{c}\text { SK } \\
\text { gov }\end{array}$ & $\begin{array}{c}\text { SK } \\
\text { uni }\end{array}$ \\
\hline 1995 & 65.1 & 26.5 & 1.0 & 43.4 & 25.5 & 3.7 & 38.7 & 35.1 & 1.7 & 53.9 & 40.3 & 0.0 \\
\hline 2000 & 60.0 & 25.3 & 0.5 & 44.3 & 26.1 & 2.1 & 36.1 & 32.3 & 1.7 & 65.8 & 24.7 & 0.6 \\
\hline 2005 & 63.2 & 20.0 & 1.1 & 43.2 & 28.0 & 0.5 & 31.8 & 36.4 & 2.9 & 49.8 & 29.6 & 0.3 \\
\hline 2010 & 62.0 & 19.4 & 0.8 & 59.8 & 18.5 & 0.9 & 26.6 & 35.9 & 2.5 & 42.1 & 29.9 & 0.4 \\
\hline 2011 & 60.3 & 17.6 & 0.8 & 62.4 & 15.7 & 0.9 & 30.1 & 34.6 & 2.4 & 37.2 & 27.6 & 1.8 \\
\hline \multicolumn{10}{|c|}{} \\
\hline mean & 62.0 & 23.0 & 1.4 & 45.8 & 26.1 & 1.9 & 32.9 & 35.1 & 2.3 & 53.6 & 29.9 & 0.3 \\
\hline stdev & 1.7 & 3.3 & 1.6 & 7.8 & 4.7 & 1.6 & 5.9 & 3.8 & 1.4 & 11.4 & 5.5 & 0.4 \\
\hline
\end{tabular}

Notes: stdev denotes standard deviation; bus refers to business $\mathrm{R} \& \mathrm{D}$, gov to government $\mathrm{R} \& \mathrm{D}$, and uni to university $\mathrm{R} \& \mathrm{D}$ funding; private non-profit $R \& D$ expenditures are excluded as their shares are negligible low.

S o u r c e : Eurostat 2014 - Total intramural R\&D expenditure (GERD) by sectors of performance.

Considering the Jones [1995] model, human capital may also shed light on the knowledge accumulation paradox. Human capital is a challenging concept, which is difficult to measure. Usually, it gets proxied by years of schooling or tertiary education attainment [Temple, 1999; Barro, 2001]. Table 3 indicates several discrepancies between the V4 and the EU-innovation leading countries in terms of $\mathrm{R} \& \mathrm{D}$ labor supply, both as a percentage of both total population and the economically active population (EAP). All V4 countries have increased their human capital stock, suggesting a potentially promising environment for their own future R\&D activities. The tertiary educated population has also risen in the Western EU countries, which may signal a domestic revival of interest, but more likely reflects brain gain.

\section{TABLE 3. Tertiary educated ratio in 2000-2011}

\begin{tabular}{|l|c|c|c|c|c|c|c|c|}
\hline & \multicolumn{4}{|c|}{ Tertiary educated, \% of EAP } & \multicolumn{4}{c|}{ Tertiary educated, \% of population } \\
\hline & MEAN & STDEV & MIN (year) & MAX (year) & MEAN & STDEV & MIN (year) & MAX (year) \\
\hline CZ & 34.7 & 2.4 & $31.5(2000)$ & $37.9(2009)$ & 12.5 & 2.2 & $10.6(2000)$ & $17.3(2011)$ \\
\hline HU & 31.8 & 1.8 & $28.8(2001)$ & $34.6(2011)$ & 16.7 & 2.6 & $13.1(2001)$ & $21.0(2011)$ \\
\hline PL & 30.5 & 4.3 & $25.1(2000)$ & $37.0(2011)$ & 16.1 & 3.9 & $10.4(2000)$ & $21.8(2011)$ \\
\hline SK & 31.2 & 2.1 & $27.7(2000)$ & $34.1(2011)$ & 13.1 & 2.7 & $9.2(2000)$ & $17.2(2011)$ \\
\hline AT & 37.9 & 3.3 & $31.4(2000)$ & $40.7(2004)$ & 16.4 & 0.8 & $15.8(2007)$ & $18.0(2011)$ \\
\hline GE & 43.2 & 1.3 & $41.5(2000)$ & $44.9(2011)$ & 22.1 & 1.6 & $20.1(2002)$ & $25.6(2011)$ \\
\hline NL & 49.4 & 2.4 & $45.4(2000)$ & $52.2(2011)$ & 27.3 & 2.9 & $21.8(2000)$ & $29.7(2008)$ \\
\hline
\end{tabular}

S o u r c e: data Eurostat 2014 - Persons with tertiary education attainment by age and sex (\%). 
Unemployment rates of human capital, as demonstrated in Figure 5, show that throughout the observed period both the Czech Republic and Hungary (till 2008) were more effective than other V4 countries in employing their human capital. Indeed, they exceeded the EU27 average rate of $6.1 \%$, although not those of the low R\&D unemployment leaders Austria (2.1 in 2012) and Germany (2.4 in 2012). The break-out of the global economic and financial crisis in 2008 decreased R\&D demand, which led to rising unemployment rates. The problem of available but unemployed human capital may be one of the key factors underlying low R\&D productivity in Slovakia and Poland.

FIGURE 5. Unemployment rates of tertiary educated workforce

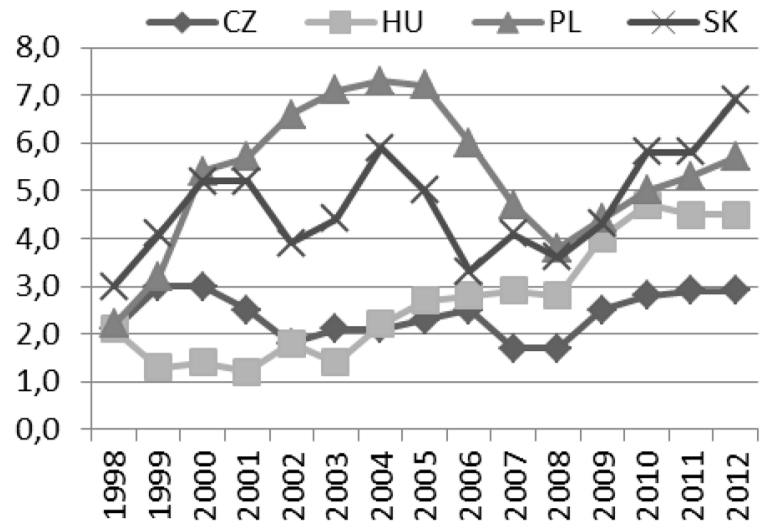

S o u r c e : Eurostat 2014 - Unemployment rates by sex, age and highest level of education attained (\%).

Figure 6 demonstrates that while the supply of human capital rises, the extent of employed R\&D workforce in all V4 countries more or less stagnated (except for massive hiring in the Czech Republic in 2004). The largest workforce employed in R\&D, per population unit, is demonstrated by Poland which is the poorest performing V4 country in terms of $\mathrm{R} \& \mathrm{D}$ productivity. The relative stability of $\mathrm{R} \& \mathrm{D}$ labor, however, is accompanied by large reallocation of the R\&D work force among sectors (Figure 7). 
FIGURE 6. R\&D labor, per millions

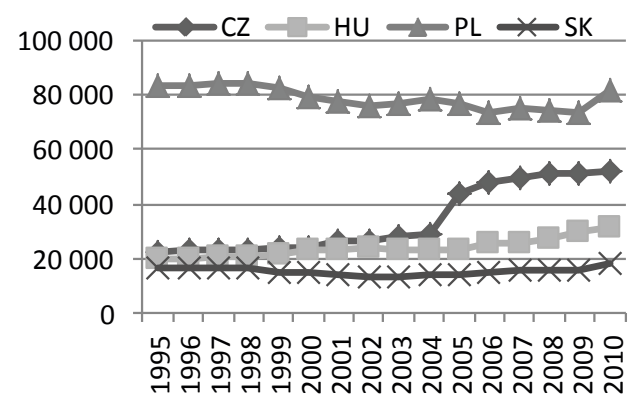

\section{FIGURE 7. Public R\&D labor, \% total}

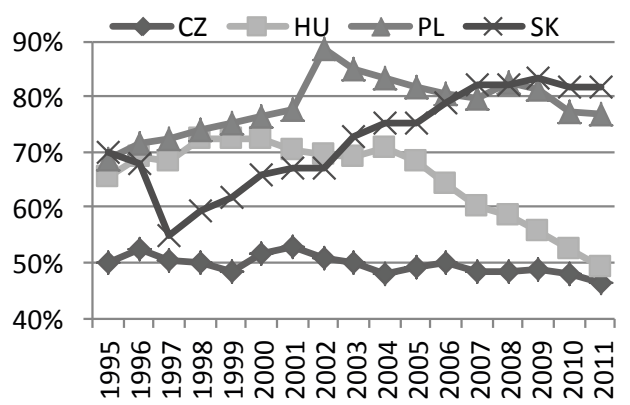

Note: public R\&D working force stands for university and government working force combined.

S o u r c e : Eurostat 2013 / Total R\&D personnel by sectors of performance, occupation and sex.

According to Eurostat, universities and governments employ the largest labor force in Slovakia and Poland (recently, approx. $80 \%$ of the total R\&D labor force), while the better R\&D performing V4 countries converge to the business labor force levels of such R\&D-intensive countries such as Germany and Denmark.

$\mathrm{R} \& \mathrm{D}$ labor is committed to producing high added value, relative to other, less innovation focused positions, is presumably rewarded with higher wages. This theorem is challenged by the theorem of FDI hiring policies and the existence of wage spillovers. FDI tends to provide higher wages than local companies in order to attract the best-performing labor force [Hijzen et al., 2013], but as Hanousek et al. [2011] note, it would be misleading to interpret this phenomenon solely as a consequence of higher productivity in FDI jobs. Since our computation of TFP [following Dujava, 2012] employs revenue-based factor shares, we omit the disturbance caused by misleading labor productivity reflected in the TFP.

Wage increase in one company is often followed by other local companies (both suppliers and competitors) [Autor et al., 2008]. As the most recent results show [for EU, see Maczulskij, 2013; for evidence involving EU and non-EU companies, see Lamo, Perez and Schuknecht, 2013], wages in FDI companies even spill over to public institutions, resulting in wage convergence across the whole $\mathrm{R} \& \mathrm{D}$ sector. The heavy reliance of the V4 countries on public R\&D can be characterized as a challenge this theorem. Table 4 reports that average annual earnings across the $\mathrm{R} \& \mathrm{D}$ sector decreased after the EU accession in the Czech Republic and Hungary. This may be imputable to the competition effect and a reallocation of production resources [Onaran, Stockhammer, 2008]. Even though public wages in these countries stayed lower than business R\&D ones, the positive trajectories of both did not change. That supports the wage spillovers literature. 
TABLE 4. Annual wages by R\&D sector, 2011 USD exchange rates, 2011 constant prices

\begin{tabular}{|l|c|c|c|c|}
\hline & MEAN & STDEV & MIN (year) & MAX (year) \\
\hline CZ R\&D bus & 28824 & 3816 & $22609(1995)$ & $34370(2010)$ \\
\hline HU R\&D bus & 29244 & 8149 & $14852(1995)$ & $38587(2005)$ \\
\hline PL R\&D bus & 26222 & 7623 & $12761(1995)$ & $40471(2008)$ \\
\hline SK R\&D bus & 24276 & 6578 & $16424(1996)$ & $37844(2010)$ \\
\hline CZ R\&D gov & 24758 & 3077 & $19474(1998)$ & $29919(2004)$ \\
\hline HU R\&D gov & 22502 & 7185 & $11330(1997)$ & $30705(2005)$ \\
\hline PL R\&D gov & 26128 & 5814 & $18133(1995)$ & $37294(2010)$ \\
\hline SK R\&D gov & 18549 & 3633 & $14086(1995)$ & $25205(2009)$ \\
\hline CZ R\&D uni & 18513 & 4765 & $8546(1996)$ & $23517(2004)$ \\
\hline HU R\&D uni & 22919 & 8913 & $9060(1997)$ & $32144(2007)$ \\
\hline PL R\&D uni & 7731 & 2894 & $5205(1996)$ & $15677(2009)$ \\
\hline SK R\&D uni & 5437 & 1287 & $3423(2002)$ & $9221(2010)$ \\
\hline
\end{tabular}

Note: bus refers to business wage, gov to government wage, uni to university wage.

S o u r c e: own calculation based on total labor costs in R\&D expenditures and R\&D employees; data OECD Stat 2014.

The lowest levels of average R\&D wages occurred in Slovakia and Poland. More interestingly, wages in the higher education sector of these countries were stagnant until 2008. This rigidity of public wages (irresponsiveness to general wage dynamics), in light of the volume of R\&D performed at universities (Table 1), reduces the chances that low labor productivity in university $\mathrm{R} \& \mathrm{D}$ will improve. First of all, lower productivity discourages $\mathrm{R} \& \mathrm{D}$ investors and, second of all, the wage gap discourages human capital to pursue a university career (it becomes a luxury to work at the university). Human capital is instead driven to the business R\&D sector - first brain drain. Even though the business sector might be selective in terms of what $\mathrm{R} \& \mathrm{D}$ areas to support (limiting the brain drain is limited through a specialization of $R \& D$ labor), this brain drain is generally conducive to $R \& D$ productivity of a country as business $R \& D$ is driven by profit motive and implicit, more productive.

To sum up, low R\&D productivity in Poland and Slovakia is related to university research funding, where most of $\mathrm{R} \& \mathrm{D}$ workforce is employed at low wages. This drives the most promising human capital out of $\mathrm{R} \& \mathrm{D}$ jobs and out of the country. 


\section{Internationalization of Slovak R\&D Sector}

The openness of small economies with low levels of domestic capital accumulation provides an opportunity for foreign capital to take advantage of the capital scarcity. However, investors in $R \& D$ are not driven by same niche-seeking that motivates non- $R \& D$ outsourcers. R\&D investors usually require specific skills and enough previous experience to give inherently risky $R \& D$ projects a reasonable prospect of success. The importance of foreign $\mathrm{R} \& \mathrm{D}$ investments for domestic growth, however, cannot be neglected [Thomson, 2013].

FIGURE 8. R\&D expenditures from abroad, \% total

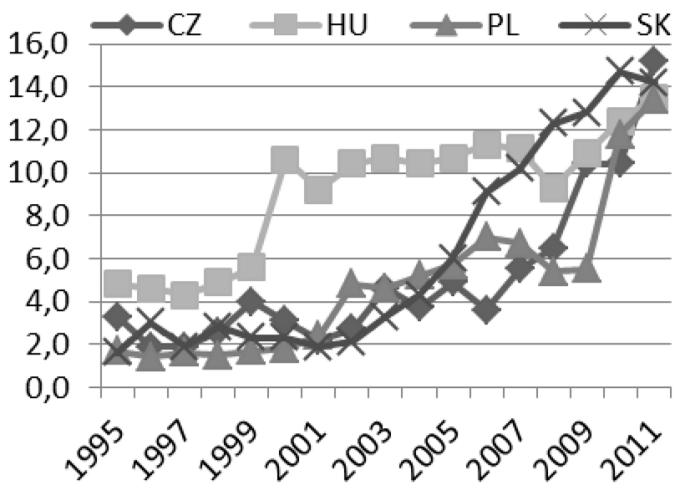

S o u r c e : Eurostat 2014 - R\&D expenditures (GERD) by source of funds (\%).

Even though all V4 countries have clearly benefited from the foreign R\&D funding boom as they entered the EU (Figure 8), they are still considerably less successful in attracting foreign $\mathrm{R} \& \mathrm{D}$ investments than other small $\mathrm{R} \& \mathrm{D}$-intensive countries. Based on Eurostat data, Austria throughout the 1995-2011 period attracted, on average, 17.3\% R\&D from abroad, and the Netherlands attracted 10.5\%,while the figures for the Czech Republic, Hungary, Poland, and Slovakia are only $5.1 \%, 9.1 \%, 4.8 \%$, and $6.2 \%$, respectively.

Combining Table 2 and Figure 8, the activation of business R\&D in Hungary in 2002 was accompanied by large R\&D inflows from abroad. Thus, we may conclude that Hungary suggests the presence of foreign $\mathrm{R} \& \mathrm{D}$ multiplier on domestic business $\mathrm{R} \& \mathrm{D}$ - transmissional (internationalization) multiplier. On the other hand, Slovakia and Poland reacted to R\&D funding from abroad with cuts in domestic public and private R\&D funding. This crowding out poses positive and negative effects. The positive effects are a learning process in which foreign investors force the domestic workforce to comply with norms and rules applied for $\mathrm{R} \& \mathrm{D}$ performance abroad. The negative effect is the risk of chronic 
dependency on foreign sources such that unless the transmissional (internationalization) multiplier kicks in, the country stagnates at the R\&D periphery.

Openness to foreign $\mathrm{R} \& \mathrm{D}$ investments is often accompanied by a rising number of EPO patent applications shared with entities abroad. As Thomson [2013] declares, such R\&D offshoring occurs in order to access niche skills in the education sector. According to Eurostat data, EPO patent volumes lag behind R\&D off shoring levels in R\&D-developed countries - e.g., Austria (which peaked in 2007 with 67 applications) or Germany (peaking in 2007 with 47 applications). Following Table 5, the V4 countries with a higher R\&D productivity also enjoyed a higher number of EPO patent applications shared with foreign co-inventors. This rising trend was reversed in 2008 after the economic crisis broke out. The significance of EPO patent applications for domestic patenting is most visible in Slovakia, where approximately $82 \%$ of all patenting activities involve foreign co-inventors, and least visible in Hungary where only $45 \%$ file with a foreign co-author. The instability of development in foreign shared EPO patent applications is represented by standard deviation and, as we may see, Slovakia and Poland demonstrate a larger variability than do the other two $\mathrm{V} 4$ countries in terms of percentage share of total EPO patent applications.

TABLE 5. EPO patent applications shared with foreign co-inventors

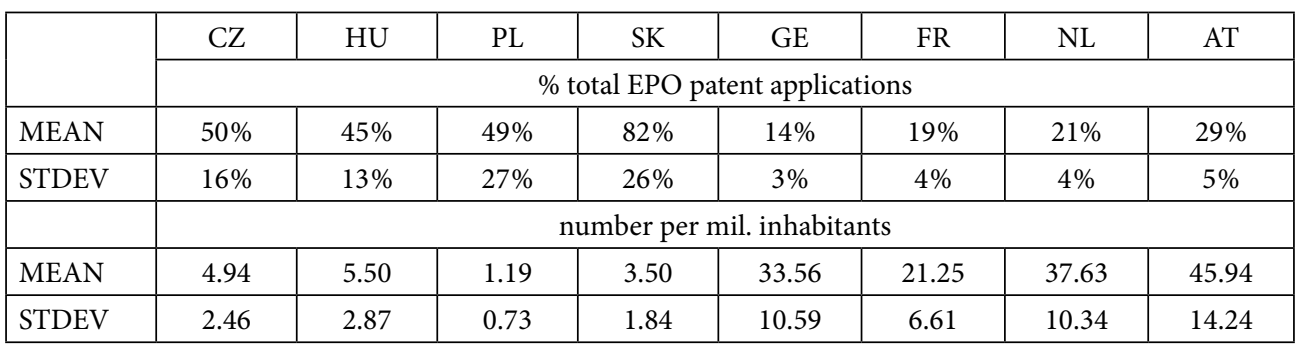

S o u r c e: Author's own calculation, data Eurostat 2014- Patent applications to the EPO with foreign co-inventors, by priority year at the national level.

Our analysis of foreign involvement in R\&D expenditures and patents indicates some dependency signals for Slovakia and Poland based on the fact that domestic R\&D funding and patenting remain irresponsive, and even declining. However, the question remains why no multiplier is in place, such that university research is associated with lower patenting but higher TFP. We assume that this phenomenon is at least partially imputable to R\&D labor flows (reallocation both locally and internationally), i.e., changes in the availability and quality of $R \& D$ labor. Considering wages, there is still a substantial opportunity for the V4 to catch-up with the Western EU and discourage R\&D labor to seek employment abroad (third brain drain). The role of wages in the brain drain was studied by Borjas [1986], Grogger and Hanson [2011], and as Weinberg [2011] and others conclude, transition countries in this context are particularly vulnerable. 


\section{Concluding Remarks}

Empirical data presented in this paper shows a discrepancy between observed TFP development and R\&D productivity in the V4 countries. Hungary is the most effective economy in terms of producing EPO patent applications with the given R\&D funds available, outperforming the Czech Republic, Slovakia, and Poland. However, both Slovakia and Poland experience faster growth of TFP. To examine the nature of this empirical phenomenon, we first studied R\&D expenditures structure and internationalization effects in the $\mathrm{R} \& \mathrm{D}$ sector and human capital formation.

The composition of $\mathrm{R} \& \mathrm{D}$ expenditures is heterogeneous among the V4. Regarding knowledge accumulation, though, the Czech Republic relies on a conventional multiplier effect of domestic public R\&D on private $R \& D$, while Hungary seems to exploit large patent applications from the transmissional (internationalization) multiplier.

In the skilled labor market, that data reveals some crucial deficiencies in knowledge-based economy building in the V4 countries, the most acute one being (in our opinion), the rigidity of public R\&D wages in Slovakia and Poland. Due to this rigidity, R\&D labor in public institutions do not currently get offered even the reservation wage, i.e., the wage that would keep them employed in the R\&D sector, and, with business wage expansion, the comparative advantage of the business sector in attracting the best performing human capital intensifies. Thus, R\&D labor loss occurs in favor of not just foreign or domestic business $R \& D$, but even the non- $R \& D$ sector where creativity is no longer being actively developed. Given that most of Slovak and Polish R\&D is performed in the public sector, low productivity translates into the overall low productivity in $\mathrm{R} \& \mathrm{D}$.

\section{Notes}

${ }^{1}$ paula.puskarova@euba.sk. The paper has been supported by the VEGA No. 1/0277/14 (V-14-046-00) Innovation and competitiveness of the Slovak economy. Usual disclaimers apply.

2 stefan.zajac@euba.sk

${ }^{3}$ According to their production input share, economies are considered either capital-intensive or labor-intensive. 


\section{References}

Autor, D.H., Katz, L.F., Kearney, M.S. (2008), Trends in U.S. wage inequality: Re-assessing the revisionists. Review of Economics and Statistics, 90(2), pp. 300-323.

Barro, R.J. (2001), Human Capital and Growth. American Economic Review, 91(2), pp. 12-17.

Borjas, G.J. (1986), The earnings of state government employees in the United States. Journal of Urban Economics, 19(2), pp. 156-173.

Dujava, D. (2012), Causes of lagging behind of new member states of EU: Empirical analysis by Montgomery decomposition. Politická ekonomie, 2, pp. 222-244.

Hanousek, J., Kocenda, E., Maurel, M. (2011), Direct and indirect effects of FDI in emerging European markets: A survey and meta-analysis. Economic Systems, 35(3), pp. 301-322.

Hijzen, A., Martins, P.S., Schank, T., Upward, R. (2013), Foreign-owned firms around the world: A comparative analysis of wages and employment at the micro-level. European Economic Review, 60, pp. 170-188.

Jones, C.I. (1995), R\&D-Based Models of Economic Growth. The Journal of Political Economy 103(4), pp. 759-784.

Keller, W. (2010), International trade, foreign direct investment, and technology spillovers. In: Hall, B.H., Rosenberg, N. (eds): Handbook of the Economics of Innovation - Volume 2. North-Holland: Elsevier, pp. 793-829.

Krammer, M.S.S. (2014), Assessing the relative importance of multiple channels for embodied and disembodied technological spillovers. Technological Forecasting \& Social Change, 81, pp. 272-286.

Lamo, A., Perez, J.J., Schuknecht, L. (2013), Are government wages interlinked with private sector wages? Journal of Policy Modeling, 35(5), pp. 697-712.

Maczulskij, T. (2013), Public-private sector wage differentials and the business cycle. Economic Systems, 37(2), pp. 284-301.

Ministry of Economy (2007), Innovation Strategy of the Slovak Republic for 2007-2013 (in Slovak), Bratislava 2007.

Ministry of Economy (2008), Innovation Policy in the Slovak Republic for 2008-2010 (in Slovak), Bratislava 2008.

Ministry of Economy (2011), Innovation Policy for 2011-2013 in the authority of the Ministry of Economy (in Slovak), Bratislava 2011.

OECD (2010), OECD Economic Surveys: Slovak Republic 2010, Paris 2010.

Onaran, O., Stockhammer, E. (2008), The effect of FDI and foreign trade on wages in the Central and Eastern European Countries in the post-transition era: A sectoral analysis for the manufacturing industry. Structural Change and Economic Dynamics, 19(1), pp. 66-80.

Puškárová, P. (2012), Inovačná výkonnost' krajín V4. In: EDAMBA 2012 [elektronický zdroj]: Proceedings of international scientific conference for doctoral students and young researchers: 22 November 2012, Bratislava / editors Martina Machová, Andrea Petianová. Bratislava, Publishing House EKONÓM, pp. 972-985.

Šikula, M. et al., (2010), Stratégia rozvoja slovenskej spoločnosti (Strategy of Slovak society development). Bratislava, VEDA.

Temple, J. (1999), A Positive Effect of Human Capital on Growth. Economic Letters, 65(1), pp. 131-134.

Thomson, R. (2013), National scientific capacity and R\&D offshoring. Research Policy, 42, pp. 517-528.

WEF (2014), The Global Competitiveness Report 2012-2013, Geneva 2014.

Weinberg, B.A. (2011), Developing science: Scientific performance and brain drains in the developing world. Journal of Development Economics, 95(1), pp. 95-104. 